\title{
Singh, T. V. (ed.) (2012). Critical Debates in Tourism. Channel View Publications. ISBN: 978-1-84541-341-5, 398 pp.
}

\author{
Reviewed by Ige Pirnar ${ }^{1}$
}

Received: 22/12/2012

\begin{abstract}
${ }^{1}$ Department of Tourism Management, Yasar University, Selcuk Yasar Campus, Faculty of Economics and Administrative Sciences, Universite Caddesi, № 35-37, Bornova, 35100 Izmir, Turkey; tel: +90232-411 5205; email: ige.pirnar@yasar.edu.tr
\end{abstract}

(c) 2013 International University College. All rights reserved

Citation: Singh, T. V. (ed.) (2012). Critical Debates in Tourism. Channel View Publications. ISBN: 978-1-84541-341-5, 398 pp., Reviewed by Ige Pirnar, European Journal of Tourism Research 6(1), 98-99.

This book which was conceived almost 15 years ago is a valuable and unique collection of challenging, contradictory and provocative, yet indeed debatable 14 topics as chapters for the book (plus an introduction and conclusion) with various papers as subtitles for these chapters written by 35 globally recognized experts and international scholars from various disciplines and backgrounds. The contributors backgrounds are spread among a wide angle from social sciences like tourism, sociology, economics and management to scientific areas like biology and engineering which gives this book its unique and special texture of being different than the already published other ones since there are opposing views, debates and views different angles for the same topic. For example, there are conflicting discussions on topics like economic impacts of tourism, nature tourism, tourism education, mass tourism, sustainability, volunteer tourism, differential small sized tourism, authenticity, etc. The paradigm and controversial issues on challenging tourism topics like climate change, socio-political, anthropological, psychological, and geographical aspects of tourism are discussed from different perspectives and views which makes this book a very valuable research material for academics, graduate students and tourism industry researchers.

The contents are grouped under 14 chapters as of follows:

1. Mass Tourism and Sustainability: Can the Two Meet?

2. Consumerism and Tourism: Are They Cousins?

3. Is Small Tourism Beautiful?

4. Does Community Participation Empower Local People

5. Does Tourism Reduce Poverty?

6. Volunteer Tourism: Is it Benign?

7. Tourism and Welfare: Seeking Symbiosis

8. Tourism Education: Quo Vadis?

9. Post Colonialism: Academic Responsibility?

10. The Dilemma of Authenticity and Inauthenticity

11. Heritage Tourism: Heritage Tourists

12. Nature-Based Tourism: There's a Lot in a Name

13. Tourism and Climate Change: A Need for Critical Analysis

14. Slow Tourism: Back to Bullock Cart Days!

Each chapter begins with outlining the context of the debated topics and ends with concluding 
remarks by the lead author and discussion questions as suggestions with an intend and possibility to lead to further studies for the debate. The conclusion part stimulating further debate and future discussions for researchers and interested parties is followed by notes and references which makes it much easier for the reader to comprehend and analyze the topic in detail for further research and discussion.

The timing and research period of the debated articles are also distributed on a wide time period, covering many topics and discussions on mainly sustainability thus containing a wide variety of opinions, facts, observations, comments, critics, findings and beliefs on; responsible tourism, ethical tourism, mass tourism, consumerism in tourism, the beauty of small tourism (or large tourism?), community participation in tourism, pre poor tourism, volunteer tourism, welfare and tourism, tourism education and controversial issues on academic studies, academic responsibility, tourism and post colonialism, authenticity in tourism, heritage tourism, nature-based tourism, climate change, and slow tourism, thus demonstrating also how tourism research after 50 years of its formal introduction so to speak, has evolved from being defined as a general context to a more scholarly and specialized manner. Thus, this book also entitles that, when compared with the past it seems that the evolution of tourism research related fields has undergone major changes leading to a more specific and specialized defined area which makes it more scholarly professional and relevant for expert studies. This innovative and very creative book which is catalogued by the Library of Congress under the headings 'Tourism - Social Aspects', and 'Tourism -
Environmental Aspects', yet as for my personal view it is really hard to catalogue this book under one suitable subtitle related to tourism field since it covers so many convergent and complex issues and topics from a wide spectrum of ecological, sustainable, economic and social aspects of tourism.

Since it is made up of highly rated academic works and articles, the language of the textbook is not simple and highly academic in general. Even though this is the case, many of the topics and concepts are very well organized therefore the language is not very hard to follow which makes this textbook a useful research material even for undergraduate students studying on social, cultural and economic aspects of tourism. The only suggestions could have been for the editor to have an author index, a more detailed subject index and listing of tables and figures to make the academic research easier for readers.

Being one of its kind "Critical Debates in Tourism" edited by Tej Vir Singh is highly advised and recommended to experts, consultants, graduate students, academic researchers, policy makers, destination management organizations and decision makers who work or study on sustainability, tourism research, heritage, nature based tourism and ecologically friendly tourism products, climate change and economic, social, cultural and environmental impacts of tourism industry on destinations, local people and in general. 